Hibah Pada Bídang Sekretariat Dínas Pendapatan dan Pengelolaan Keuangan dan Aset Daerah Kabupaten Pulang Pisau Berbasis WEB

\title{
SISTEM INFORMASI BANTUAN HIBAH PADA BIDANG SEKRETARIAT DINAS PENDAPATAN DAN PENGELOLAAN KEUANGAN DAN ASET DAERAH KABUPATEN PULANG PISAU BERBASIS WEB
}

\author{
Susi Hendartie ${ }^{1}$, Bayu Pratama Nugroho ${ }^{2}$, Epha Erlina ${ }^{3}$ \\ Program Studi Sistem Informasi, Sekolah Tinggi Manajemen Informatika dan Komputer \\ (STMIK) Palangkaraya \\ Jl. G.Obos No. 114, Palangka Raya, 73112 Kalimantan Tengah Telp: 0536-3225515, 0536-3224593 \\ Email: susihendartie@gmail.com ${ }^{1}$, bayupratama1988@gmail.com² ${ }^{2}$, ephaerlina9@gmail.com ${ }^{3}$
}

\begin{abstract}
ABSTRAK
Bantuan dana hibah adalah program pemerintah untuk meningkatkan kesejahteraan masyarakat yang disalurkan kepada masyarakat atau organisasi masyarakat yang berhak. Sehingga diharapkan dalam pengelolaan dana hibah dapat dikelola dengan baik dan dapat memberikan informasi yang transparan kepada masyarakat atau organisasi masyarakat yang mengajukan bantuan hibah. Penelitian yang dilakukan bertujuan untuk mengetahui dan menganalisis permasalahan yang menjadi kendala dan hambatan dalam pengelolaan dana hibah serta memberikan solusi untuk membantu penyelesaian masalah yang terjadi pada Bidang Sekretariat Dinas Pendapatan Dan Pengelolaan Keuangan Dan Aset Daerah Kabupaten Pulang Pisau. Permasalahan yang ditemukan pada Bidang Sekretariat Dinas Pendapatan Dan Pengelolaan Keuangan Dan Aset Daerah Kabupaten Pulang Pisau sebagai pelaksana kegiatan adalah pelayanan publik masih dilakukan dengan cara manual dan untuk pengelolaan berkas menggunakan aplikasi office sehingga dalam pelayanan masih belum maksimal. Terkait dengan sistem yang lama maka dalam penelitian ini penyelesaian permasalahan yang digunakan adalah dengan menggunaan metode pengembangan sistem Waterfall. Tujuan dari penggunaan metode waterfall agar sistem ini dapat dianalisis, dirancang dan dibangun dengan proses yang urut sehingga dapat dikembangkan sesuai dengan kebutuhan/dikehendaki (tepat sasaran). Berdasarkan hasil penelitian ini ditemukan bahwa dengan adanya sistem informasi berbasis web sangat memberikan manfaat dalam pengelolaan dana hibah terutama meningkatkan pelayanan publik serta meningkatkan informasi agar lebih transparan bagi pihak pada Bidang Sekretariat Dinas Pendapatan Dan Pengelolaan Keuangan Dan Aset Daerah maupun lembaga masyarakat calon penerima/penerima dana hibah di kabupaten Pulang Pisau.
\end{abstract}

Kata Kunci : Sistem Informasi, Dana Hibah, Waterfall, Web

\begin{abstract}
Grant fund assistance is a government program to improve community welfare distributed to the community or entitled community organizatuions. So it is hoped that the management of grant funds can be well managed and can provide transparent information to the community or community organizatuions. The research carried out aims to identify and analyze the problems that become obstacles and obstacles in the management of grant funds and provide solutions to help resolve problems that occur in the Department of Revenue and Financial and Asset Management in Pulang Pisau Regency. The problem found in the Secretariat of the Regional Office of Revenue and Financial and Asset Management of Pulang Pisau Regency as the implementer of activities is that public services are still carried out manually and for file management using office applications so that services are still not optimal. Associated with the old system, in this study the problem solving used is by using the Waterfall system development method. The purpose of using the waterfall method is so that this system can be analyzed, designed and built with a sequential process so that it can be developed according to needs / desired (right on target). Based on the results of this study, it was found that the existence of a web-based information system was very beneficial in managing grant funds, especially improving public services and increasing information to make it more transparent for parties in the Secretariat of the Office of Regional Revenue and Financial and Asset Management as well as the community of prospective recipients of grant funds. in Pulang Pisau district.
\end{abstract}

Keywords: Information Systems, Grants, Waterfall, Web

\section{PENDAHULUAN}

Program pemerintah yang bertujuan untuk mensejahterakan negara dibuktikan dengan menyelenggarakan berbagai kebijakan salah satunya adalah program hibah dan bantuan sosial. Bantuan hibah dan bantuan sosial 
diberikan oleh pemerintah daerah kepada masyarakat atau organisasi masyarakat yang berhak menerimanya.

Pemerintah daerah kabupaten Pulang Pisau melaksanakan kegiatan pemberian bantuan hibah dan sosial melalui Bidang Sekretariat Dinas Pendapatan Dan Pengelolaan Keuangan Dan Aset Daerah. Bidang ini yang bertugas mengelola anggaran pendapatan dan belanja daerah, aset daerah dan juga bertindak sebagai bendahara Umum Daerah serta melaksanakan kegiatan pemberian hibah dan bantuan sosial.

Dinas Pendapatan, Pengelola Keuangan dan Aset Daerah kabupaten Pulang Pisau mempunyai tugas menyusunan dan melaksanaan kebijakan daerah serta menetapkan penggunaan anggaran belanja bantuan sosial kepada rumah ibadah, pembinaan kegiatan keagamaan dan kelembagaan kegiatan keagamaan.

Pelayanan publik terkait dengan bantuan dana hibah dan bantuan sosial saat ini masih dilakukan secara manual, masyarakat harus ke kantor dinas pendapatan untuk menemukan dan mendapatkan informasi terkait dengan bantuan, untuk mengetahui kepada siapa dana hibah dan bansos disalurkan dan apa saja persyaratan yang harus dipenuhi. Masyarakat pun harus datang langsung untuk melakukan pengajuan serta untuk mengetahui informasi apakah proposal yang diajukan diterima atau ditolak. Sistem yang digunakan untuk mengelola dana hibah dan bantuan sosial menggunakan aplikasi office sehingga pengelolaan dana hibah kurang maksimal dalam transparansi dan akuntabilitas.
Permasalahan yang terjadi dalam pelayanan publik serta pengelolaan dana hibah dan bantuan sosial pada pemerintah daerah kabupaten Pulang Pisau mengakibatkan kurang maksimalnya layanan publik serta pengelolaan dana hibah dan dana sosial sehingga diperlukan sistem informasi dalam pelayanan serta pengelolaan berbasis web sebagai media online untuk menyelesaikan permasalahan tersebut.

\section{TINJAUAN PUSTAKA}

\subsection{Konsep Dasar Sistem Informasi}

Terdapat berbagai macam pengertian sistem informasi menurut beberapa "Sistem informasi adalah suatu sistem didalam suatu organisası yang mempertemukan kebutuhan pengolahan transaksi harian yang mendukung fungsi operasi organisası yang bersifat manajerial dengan kegiatan strategi dan suatu organisasi untuk dapat menyediakan kepada pihak luar tertentu dengan laporan laporan yang diperlukan".

Menurut Sutarman (2012:13). "Sistem dapat didefinisikan dengan mengumpulkan, memperoses, menyimpan, menganalisis, menyebarkan informasi untuk tujuan tertentu. Seperti sistem lainnya, sebaah sistem infortnas1 terdiri atas input (data, instruksi) dan output (laporan, kalkulasi)" .

Menurut Mulyanto (2009 29), "Sistem informasi adalah suatu komponen yang terdiri dari manusia, teknologi informası, dan prosedur kerja yang memproses menyimpan, menganalısis, dan menyebarkan informasi untuk mencapai suatu tujuan". 
Hibah Pada Bidang Sekretariat Dinas Pendapatan dan Pengelolaan Keuangan dan Aset Daerah Kabupaten Pulang Pisau Berbasis WEB

\subsection{Hibah}

Menurut Permendagri Nomor 32 Tahun 2011, hibah adalah pemberian uang/barang atau jasa dari pemerintah daerah kepada pemerintah atau pemerintah daerah lainnya, perusahaan daerah, masyarakat dan organisasi masyarakat yang secara spesifik telah ditetapkan peruntukkannya, bersifat tidak wajib dan tidak mengikat serta tidak secara terus menerus yang bertujuan untuk menunjang penyelenggaraan urusan pemerintah daerah.

Dalam Pemendagri Nomor 32 Tahun 2011, dijelaskan bahwa hibah dapat diberikan kepada pemerintah, perusahaan daerah, masyarakat, dan organisasi kemasyarakatan. Adapun syarat yang harus dipenuhi penerima hibah adalah sebagai berikut. Pertama hibah kepada masyarakat diberikan dengan persyaratan memiliki kepengurusan yang jelas, yang dibuktikan oleh surat keputusan pejabat yang berwenang, berkedudukan dalam wilayah administrasi tertentu yang diakui pemerintah dan mempunyai program dan kegiatan yang jelas dalam menunjang program pemerintah. Kedua, hibah kepada organisasi kemasyarakatan diberikan dengan persyaratan telah terdaftar pada pemerintah daerah sekurang-kurangnya tiga tahun (kecuali ditentukan lain oleh peraturan perundang undangan), berkedudukan dalam wilayah administrasi kabupaten/kota, memiliki kepengurusan yang jelas yang dibuktikan dengan akta pendirian dan/atau surat keputusan pejabat yang berwenang, mempunyai sekretariat yang tetap dan jelas, dan mempunyai program dan kegiatan yang jelas yang menunjang program pemerintah.

\subsection{Data Flow Diagram (DFD)}

Menurut Sukamto dan Shalahuddin (2013:70) "Data Flow Diagram (DFD) atau dalam bahasa Indonesia menjadi Diagram Alir Data (DAD) adalah representasi grafik yang menggambarkan aliran informasi dan transformasi informasi yang diaplikasikan sebagai data yang mengalir dari masukan (input) dan keluaran (output)".

DFD dapat digunakan untuk merepresentasikan sebuah sistem atau perangkat lunak pada beberapa level yang lebih detail untuk merepresentasikan aliran informasi atau fungsi yang lebih detail. DFD menyediakan mekanisme untuk pemodelan fungsional ataupun pemodelan aliran informasi.

Berikut ini adalah tahapan-tahapan peracangan dengan menggunakan DFD:

a. Membuat DFD Level 0 atau sering disebut juga Context Diagram, DFD Level 0 menggambarkan sistem yang akan dibuat sebagai suatu etitas tunggal yang berinteraksi dengan orang maupun sistem lain. DFD Level 0 digunakan untuk menggambarkan interaksi antara sistem yang akan dikembangkan dengan entitas luar.

b. Membuat DFD Level, DFD Level 1 digunakan untuk menggambarkan modulmodul yang ada dalam sistem yang akan dikembangkan. DFD Level 1 merupakan hasil breakdown DDFD Level 0 yang sebelumnya sudah dibuat. 


\section{Jurnal Sains Komputer dan Teknologi Informasi Page e - issn : 2655-7460. Volume 3 No.1, November 2020 $83 \sim 92$}

c. Membuat DFD Level 2, Modul-modul pada DFD Level 1 dapat di-breakdown menjadi DFD Level 2. Modul mana saja yang harus di-breakdown lebih detail tergantung pada tingkat kedetailan modul tersebut. Apabia modul tersebut sudah cukup detail dan rinci maka modul tersebut sudah tidak perlu dibreakdown lagi. Untuk sebuah sistem, jumlah DFD Level 2 sama dengan jumlah modul pada DFD Level 1 yang di-breakdown.

d. Membuat DFD Level 3 dan seterusnya, DFD Level $3,4,5, \quad$ dan seterusnya merupakan breakdown dari modul pada DFD Level di-atasnya. Breakdown pada level $3,4,5$, dan seterusnya aturannya sama persis dengan DFD Level 1 atau Level 2.

\subsection{Pengenalan Umum Hypertext Prepocessor (PHP)}

PHP merupakan bahasa script yang dapat ditanamkan atau disisipkan kedalam HTML. PHP banyak dipakai untuk memrogram situs web dinamis, walaupun tidak tertutup kemungkinan digunakan untuk pemakaian lain.

Menurut Madcoms (2008:195) PHP adalah salah satu bahasa pemograman yang berjalan dalam sebuah web server dan berfungsi sebagai pengolah data pada sebuah server.

a. Web Server yang mendukung PHP dapat ditemukan dimana - mana dari mulai apache, IIS, Lighttpd, hingga Xitami dengan konfigurasi yang relatif mudah.

b. Dalam sisi pengembangan lebih mudah, karena banyaknya milis - milis dan developer yang siap membantu dalam pengembangan. c. Dalam sisi pemahamanan, PHP adalah bahasa scripting yang paling mudah karena memiliki referensi yang banyak.

d. PHP adalah bahasa open source yang dapat digunakan di berbagai mesin (Linux, Unix, Macintosh, Windows) dan dapat dijalankan secara runtime melalui console serta juga dapat menjalankan perintah-perintah system.

\subsection{MySQL}

MySQL adalah sebuah implementasi dari sistem manajemen basisdata relasional (RDBMS) yang didistribusikan secara gratis. Setiap pengguna dapat secara bebas menggunakan MySQL, namun dengan batasan perangkat lunak tersebut tidak boleh dijadikan produk turunan yang bersifat komersial. MySQL sebenarnya merupakan turunan salah satu konsep utama dalam basisdata yang telah ada sebelumnya; SQL (Structured Query Language).

SQL adalah sebuah konsep pengoperasian basisdata, terutama untuk pemilihan atau seleksi dan pemasukan data, yang memungkinkan pengoperasian data dikerjakan dengan mudah secara otomatis.

\subsection{Definisi Website}

World Wide Web (biasa disingkat WWW) atau merupakan salah satuaplikasi internet yang paling popular. Web adalah sebuah sistem dimana informasi dalam bentuk teks, gambar, suara dan lainnya yang tersimpan dalam sebuah internet webserver ditampilkan dalam bentuk HTML (hypertext Markup Language) (Sutanta, 2005:546). 
Susi Hendartie, Bayu Pratama Nugroho dan Epha Erlina. Sistem Informasi Bantuan 2020

Hibah Pada Bidang Sekretariat Dinas Pendapatan dan Pengelolaan Keuangan dan Aset Daerah Kabupaten Pulang Pisau Berbasis WEB

Pengertian lain web atau WWW adalah dokumen atau infomasi yang saling berhubungan yang dihubungkan melalui hyperlink atau URL (Uniform Resource Locator) (Syafrudin \& Eko, 2008:9)

\subsection{Notepad++}

Notepad++ adalah sebuah aplikasi untuk menuliskan kode atau script web. Notepad++ menggunakan komponen Scintilla untuk dapat menampilkan dan menyuntingan teks dan berkas kode sumber berbagai bahasa pemrograman.

\section{METODE PENELITIAN}

Metode penelitian yang diterapkan pada penelitian ini adalah dengan pengembangan sistem model Waterfall.Dimana setiap tahap dilakukan secara sistematikdan sekuensial seperti air terjun melewati setiap fase-fase. Adapun penjabaran tahapan menurutSommerville (2011, p30) adalah sebagai berikut

a. Requirement Analysis and Definition (Analisis dan Definisi Kebutuhan), adalah tahapan penetapan fitur, kendala dan tujuan sistem melalui konsultasi dengan pengguna sistem. Semua hal tersebut akan ditetapkan secara rinci dan berfungsi sebagai spesifikasi sistem.

b. System and Software Design (Desain Sistem dan Perangkat Lunak), Pada Tahap System and Software Design ini akan dibentuk suatu arsitektur sistem berdasarkan persyaratan yang telah ditetapkan. Selain itu juga, dilakukan identifikasi dan penggambaran terhadap abstraksi dasar sistem perangkat lunak beserta hubungan-hubungannya.

c. Implementation and Unit Testing (Implementasi dan Pengujian Unit), Dalam tahapan Implementation and Unit Testing ini, hasil dari desain perangkat lunak akan direalisasikan sebagai satu set program atau unit program. Setiap unit akan diuji apakah sudah memenuhi spesifikasinya.

d. Integration and System Testing (Integrasi dan Pengujian Sistem), Dalam tahap Integration and System Testing ini, setiap unit program akan diintegrasikan satu sama lain dan diuji sebagai satu sistem yang utuh untuk memastikan sistem sudah memenuhi persyaratan yang ada. Setelah itu sistem akan dikirim ke pengguna sistem.

e. Operation and Maintenance (Operasi dan Pemeliharaan), Dalam tahap Operation and Maintenance ini, sistem diinstal dan mulai digunakan. Selain itu juga memperbaiki error yang tidak ditemukan pada tahap pembuatan. Dalam tahap ini juga dilakukan pengembangan sistem seperti penambahan fitur dan fungsi baru.

\section{HASIL DAN PEMBAHASAN}

\subsection{Analisis Kebutuhan}

Analisis digunakan sebagai acuan dalam tahapan pembuatan program atau aplikasi sehingga program dapat dibuat dengan lebih terencana dan terarah serta layak untuk dibuat dan diimplementasikan.

Tahapan analisis yang yang dijelaskan adalah analisis kelemahan sistem yang berjalan 


\section{Jurnal Sains Komputer dan Teknologi Informasi Page e - issn : 2655 7460. Volume 3 No.1, November 2020

untuk mengidentifikasi dan mengevaluasi permasalahan-permasalahan sehingga dapat diusulkan perbaikan-perbaikan atau solusi yang meliputi analisis kebutuhan sistem seperti kebutuhan informasi, perangkat keras (hardware), perangkat lunak (software) dan kebutuhan pengguna.

\subsubsection{Analisis Sistem yang Berjalan}

Pada sistem yang berjalan pelayanan publik masih menggunakan cara manual; pemohon datang ke kantor dinas untuk melihat pengumuman yang ditempelkan di papan pengumuman tentang persyaratan hibah kemudian pengambilan formulir pemohonan dana dan pengajuan permohonan dana dilayani langsung dengan pegawai yang berwenang. Dan pegawai yang bertugas akan mengelola data yang telah diajukan oleh pemohon dengan menggunakan aplikasi office.

\subsubsection{Analisis Kebutuhan Sistem}

Analisis Kebutuhan sistem dilakukan untuk mengetahui kebutuhan yang diperlukan untuk mengembangkan aplikasi. Analisis dilakukan dengan mencari dan menentukan beberapa kebutuhan seperti kebutuhan perangkat keras, kebutuhan perangkat lunak, kebutuhan informasi dan kebutuhan pengguna.

a. Kebutuhan Perangkat Keras

Adapun kebutuhan perangkat keras yang diperlukan untuk membangun sistem informasi berbasis web adalah :

- Komputer/Laptop

- UPS (Unitteratible Power Supplay)

b Kebutuhan Perangkat Lunak
Adapun perangkat lunak yang digunakan dalam pembuatan sistem ini adalah :

- Windows 7 Ultimate, sebagai sistem operasi

- ADOBE Dreamweaver CS5

- Web Browser digunakan untuk menampilkan halaman web baik secara online maupun offline misalnya Mozila Firefox, Opera, Google Chrome dan Internet Explorer.

- XAMPP / Appserv

- Notepad ++, sebagai program editor yang digunakan untung editing html maupun PHP

c. Kebutuhan Informasi

Dalam perancangan nantinya yang perlu diperhatikan dan dipenuhi dalam pengimplementasian sistem informasi adalah:

- Informasi data dana hibah

- Informasi Berita dan informasi kegiatan dinas

- Informasi syarat ketentuan hibah

- Pengajuan dana hibah secara online

- Laporan Pengajuan dana hibah

d. Kebutuhan Pengguna

Adapun kebutuhan penggunanya adalah :

- Administrator, bertugas untuk menjalankan dan mengelola sistem informasi yang dibuat.

- Masyarakat, sebagai pengguna umum dapat melihat informasi yang ditampilkan web dan dapat mengajukan hibah pada form yang telah disediakan.

\subsection{Desain Sistem}


Susi Hendartie, Bayu Pratama Nugroho dan Epha Erlina. Sistem Informasi Bantuan 2020

Hibah Pada Bidang Sekretariat Dinas Pendapatan dan Pengelolaan Keuangan dan Aset Daerah Kabupaten Pulang Pisau Berbasis WEB

Untuk menggambarkan sistem yang akan dibangun maka penelitian ini di desain dengan menggunakan Data Flow Diagram atau Diagram Arus Data (DAD) dengan tahapan sebagai berikut :

a. Diagram Konteks.

Disini admin bertindak sebagai pengelola data yang memiliki data master semua informasi dan masyarakat baik itu dinas ataupun masyarakat sebagai pihak penerima informasi.
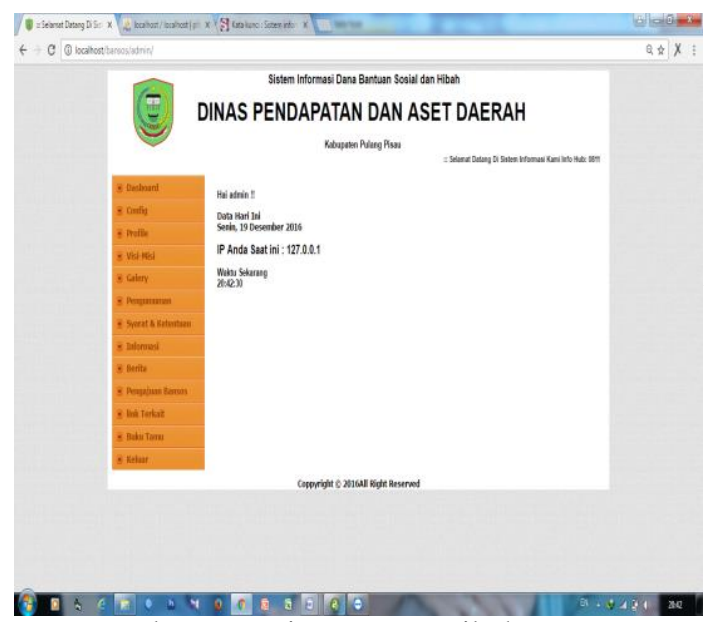
tamu dan Pengajuan Dana Hibah.

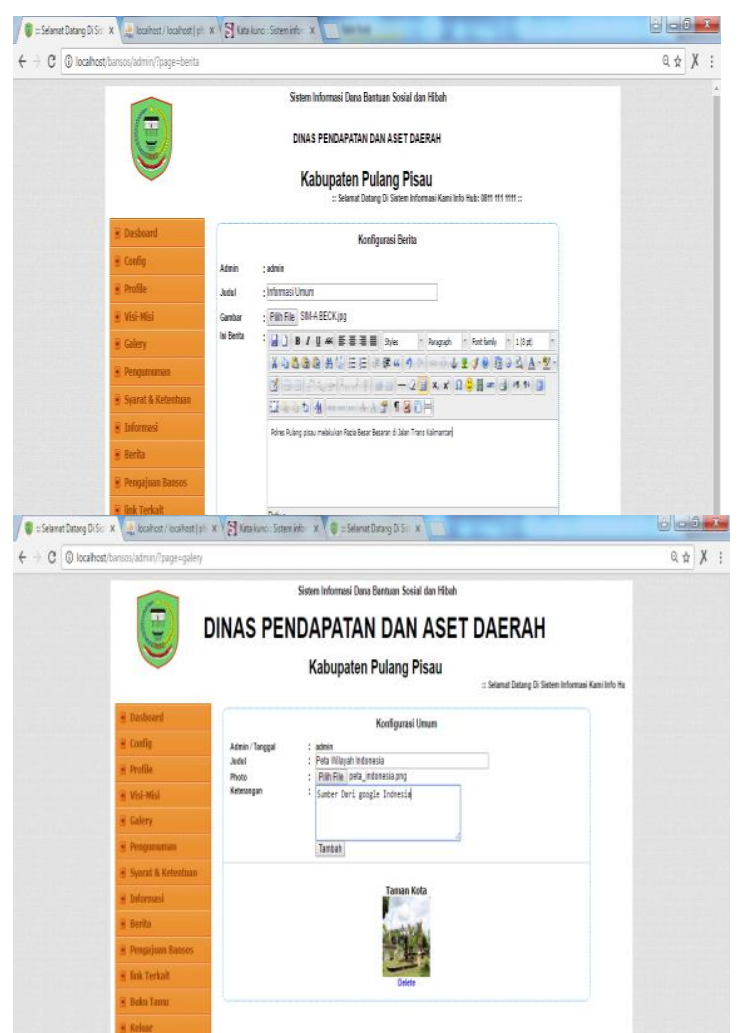

Admin melakukan proses tambah data admin, edit data admin dan hapus data admin.

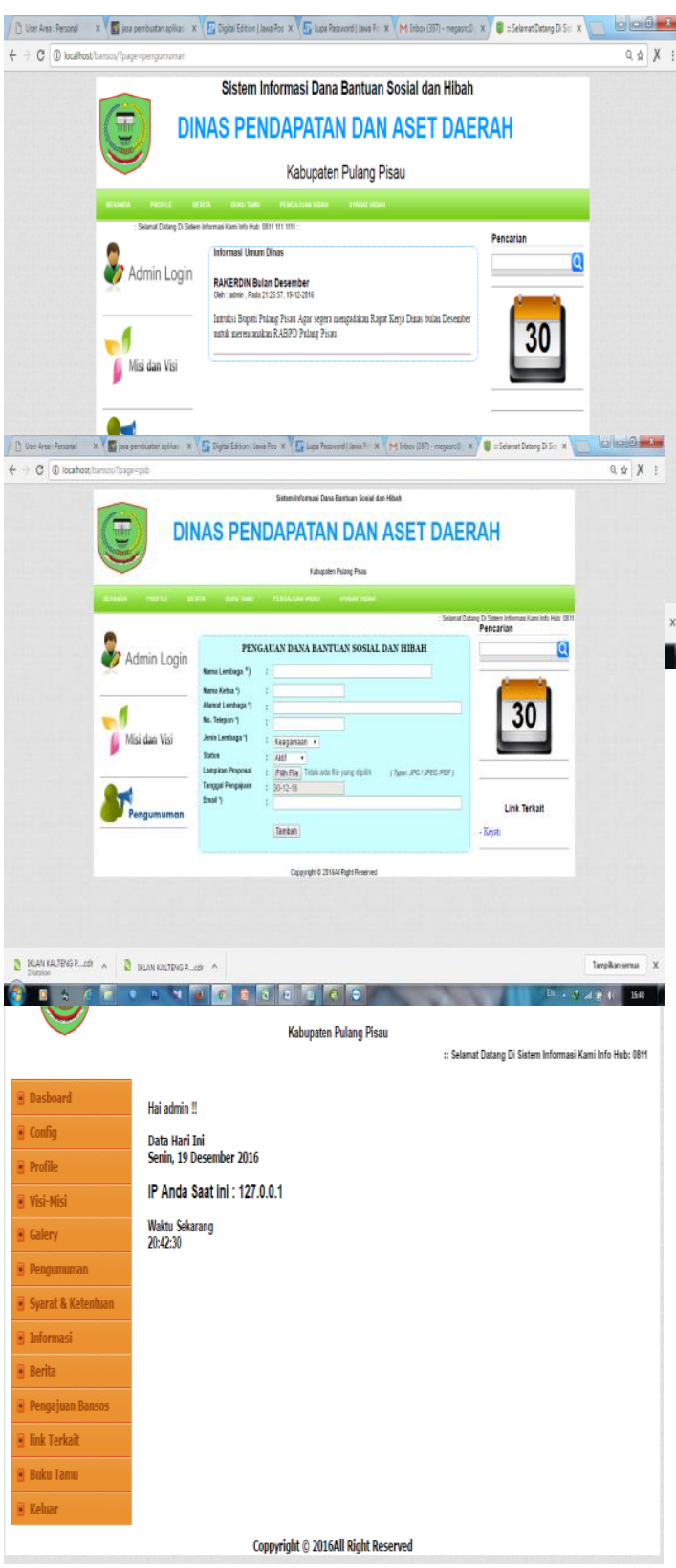

Gambar 6. Tampilan Halaman Utama

b. Tampilan form Input Berita 


\section{Jurnal Sains Komputer dan Teknologi Informasi Page e - issn : 2655 7460. Volume 3 No.1, November 2020

Kabupaten Pulang Pisau

:: Selamat Datang Di Sistem Informasi Kami Info Hub: 08111111111 ::

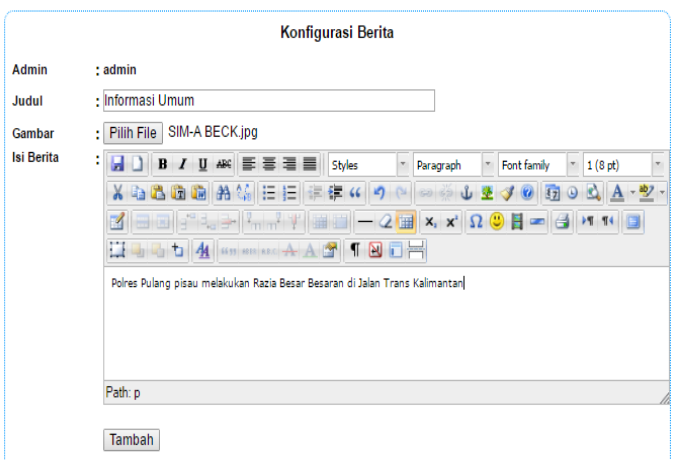

Gambar 7. Tampilan form Input Berita

c. Tampilan form Input Galeri

\section{Kabupaten Pulang Pisau}

" Selamat Datang Di Sistem Informasi K

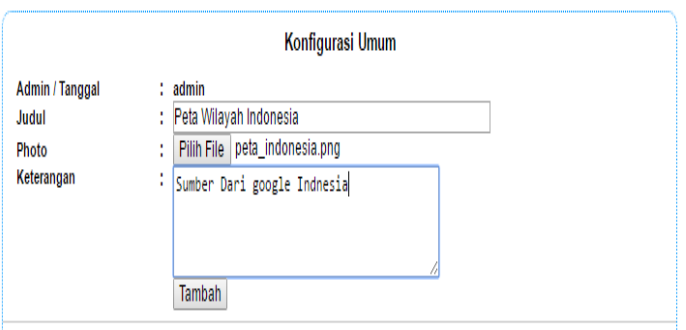

Gambar 8. Tampilan form Input Galeri

d. Tampilan Input Pengumuman

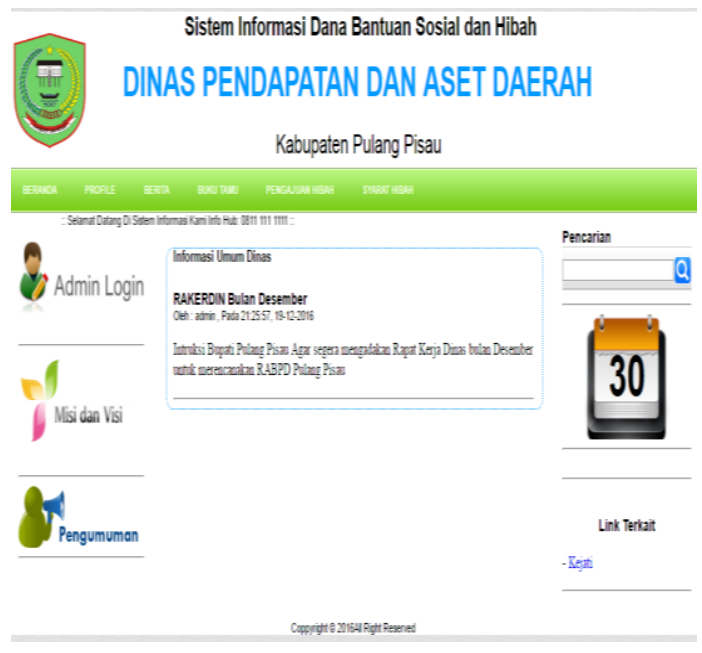

Gambar 9. Tampilan form Input Pengumuman e. Tampilan form Input Konfigurasi Umum

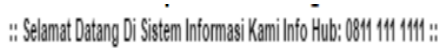

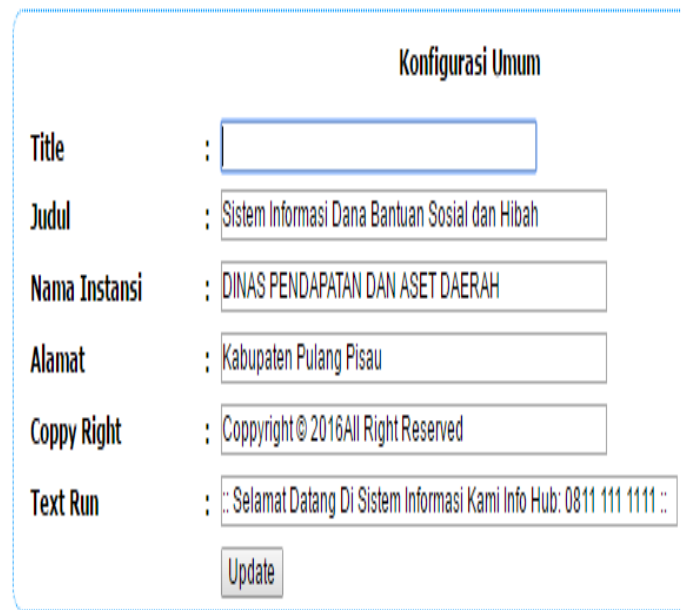

Gambar 10. Tampilan form Input Konfigurasi Umum

f. Tampilan form input Pengajuan

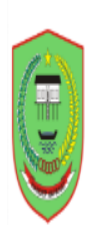

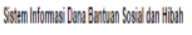

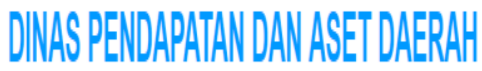

Katurite Pulag Psian
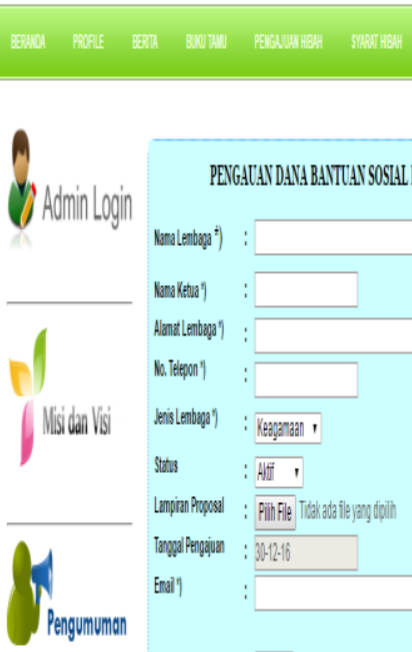

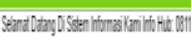
Panceritian

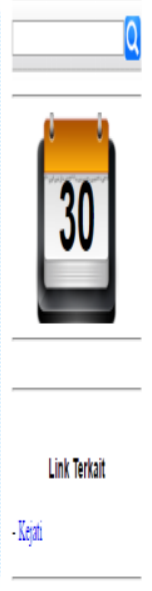

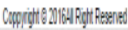


Susi Hendartie, Bayu Pratama Nugroho dan Epha Erlina. Sistem Informasi Bantuan

Hibah Pada Bidang Sekretariat Dinas Pendapatan dan Pengelolaan Keuangan dan Aset Daerah Kabupaten Pulang Pisau Berbasis WEB

Gambar 11. Tampilan form input Pengajuan

g. Tampilan menu Laporan Pengajuan

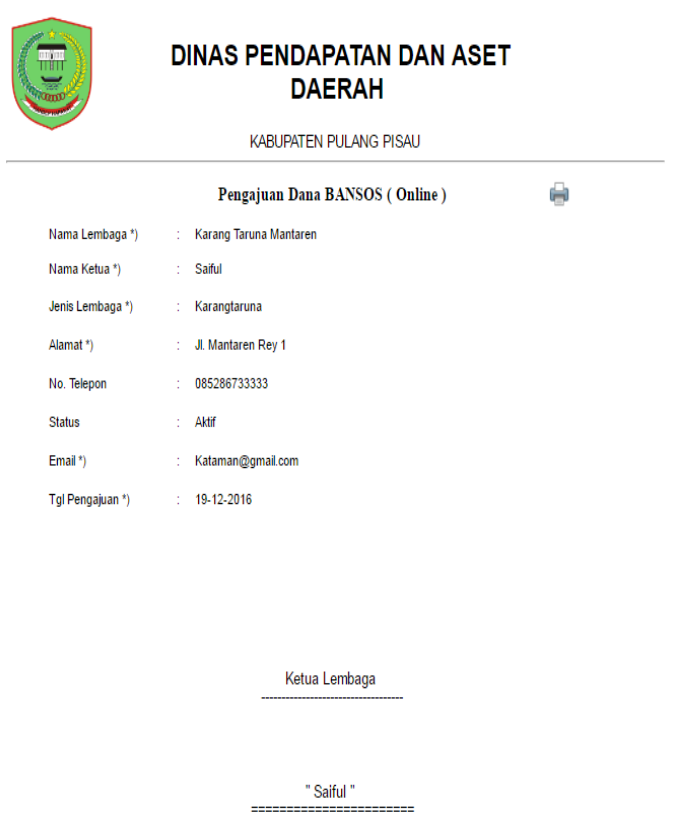

Gambar 12. Tampilan menu Laporan Pengajuan

\section{KESIMPULAN}

Berdasarkan hasil penelitian dan pembahasan pada bagian sebelumnya maka dapat ditarik kesimpulan sebagai berikut: 1) Sistem Informasi Bantuan Hibah berbasis web mempengaruhi layanan publik dan pengelolaan dana hibah di bidang sekretariat dinas pendapatan dan pengelola keuangan dan aset daerah kabupaten Pulang Pisau. Pemohon bisa mendapatkan informasi mengenai ketersediaan dana hibah di halaman pengumuman dan berita pada web yang telah disediakan. Dan pemohon dapat mengajukan permohonan dana hibah secara mengririmkan file persyaratan secara online melalui web. 2) Informasi penerima hibah disampaikan dengan transparan melalui halaman pengumuman dan berita sehingga dapat diketahui oleh semua pihak yang berkepentingan.

\section{DAFTAR PUSTAKA}

Aditya Nur Alan, 2011. Jago Php dan MySQLDalam Hitungan Menit, Dunia Komputer, Bekasi.

Don Ho, 2016. Notepad++. https://notepadplus-plus.org/ (diakses 28 Desember 2016)

DCMA. 2014. Pengertian PHP .http://www.temukanpengertian.com/20 14/12/pengertian-php.html. (diakses 28 Desember 2016 )

Kadir, Abdul. 2008. Dasar Pemrograman WebDinamis Menggunakan PHP. Edisi Revisi. Penerbit Andi. Yogyakarta.

Madcoms, 2008. Mahir Dalam 7 Hari Adobe Dreamweaver CS3 dan PHP, Andi, Yogyakarta.

Madcoms, 2012. Java Script Untuk Membangun Website Profesional, Andi, Yogyakarta.

Mustakini, Jogiyanto Hartono. 2009. "Sistem Informasi Teknologi". Andi Offset. Yogyakarta.

Mulyanto. 2009. "Sistem Informasi Konsep Dan Aplikasi". Pustaka Pelajar. Yogyakarta

Nugroho, Candra Setya dan Setiawan, Wawan Dharma. 2017. Model Inovasi Hibah dan Bansos Online Kota Bandung. Jurnal Wacana Kinerja, Volume 20|Nomor 1| Juni 2017

Sommerville, Ian. 2011. "Software Engineering Rekayasa Perangkat Lunak". Erlangga. Jakarta.

Sutarman. 2012. "Buku Pengantar Teknologi Informasi". Bumi Aksara. Jakarta. 


$$
\begin{array}{r|l}
\text { Jurnal Sains Komputer dan Teknologi Informasi } & \text { Page } \\
\text { e-issn : 2655-7460. Volume 3 No.1, November 2020 } & 83-92
\end{array}
$$

Syarifudin, S.T dan Eko. 2008. Koneksi Internet untuk PC, Laptop dan HP. MediaKom. Yogyakarta.

Wahana Komputer, 2012. Mudah Membuat Portal Berita Online dengan PHP dan $M y S Q L$, Andi, Yogyakarta.

Yakub. 2012. "Pengantar Sistem Informasi". Graha Ilmu. Yogyakarta.

\section{Peraturan dan Perundang-undangan :}

Permendagri No. 32 Tahu 2011 tentang Pedoman Pemberian Hibah dan Bantuan Sosial yang bersumber dari Dana Anggaran Pendapatan Belanja Daerah 